\title{
Hypothermia Regulates Endoplasmic Reticulum (ER) Stress through the X-box Binding Protein-1 (XBP1) Gene Expression in PC12 Cells
}

\author{
Bo-Kyung Yoo ${ }^{1, \$}$, Kisang Kwon ${ }^{2,8}$, Eun Ryeong Lee ${ }^{2}$ and O-Yu Kwon ${ }^{1, \uparrow}$ \\ ${ }^{I}$ Department of Anatomy \& Cell Biology, College of Medicine, Chungnam National University, \\ Daejeon 35015, Korea \\ ${ }^{2}$ Department of Biomedical Laboratory Science, College of Health \& Welfare, Kyungwoon University, \\ Gumi 39160, Korea
}

\begin{abstract}
Endoplasmic reticulum (ER) stress induces unfolded protein response (UPR) via inositol-requiring enzyme 1 (IRE1) activation, which sends a molecular signal for X box-binding protein 1 (XBP1) mRNA splicing in the cytosol. IRE1 endoribonuclease activity induces cleavage of XBP1 mRNA. The XBP1 mRNA is then ligated by an uncharacterized RNA ligase and translated to produce spliced XBP1 by $23 \mathrm{nt}$ removed in which contains the PstI restriction enzyme site. The splicing of XBP1 mRNA can be detected by semiquantitative RT-PCR, and then splicing of XBP1 is a useful tool to measure the genetic variability in ER stress. In this study, we have estimated IRE1-dependent splicing of XBP1 mRNA under conditions of various hypothermia. The results indicated that hypothermia regulated ER stress. This study demonstrated that hypothermia is closely related to ER stress and may be useful for early diagnosis of ER-associated disease.
\end{abstract}

Key Words: Hypothermia, Endoplasmic Reticulum (ER) Stress, X-box Binding Protein-1 (XBP1)

진핵세포에서 소포체(endoplasmic reticulum: ER)의 주된 생물학적 기능은 신생 단백질의 번역 후 변형 과정(posttranslational modification step)을 수행하는 것이다. 즉, 소 포체는 mRNA에서 새롭게 만들어진 미완성의 polypeptide 가 정상적인 기능을 가진 분비/막 단백질이 되기 위하여 folding \& assembly, glycosylation adding \& trimming 등의 과 정을 정확하게 수행할 수 있도록 최적의 조건을 제공하 는 세포내 소기관이다(Schwarz and Blower, 2016). 이와 같 은 기능을 중추적으로 수행하는 ER lumen에 존재하는 단 백질무리를 소포체 분자샤페론(ER molecular chaperone)이 라고 한다. 지금까지 보고된 대표적인 것으로는 binding immunoglobulin protein (BiP), glucose-regulated protein 94 (GRP94), endoplasmic reticulum protein (Erp72), protein disul- fide isomerase (PDI), calnexin, calreticulin, endoplasmic reticulum 29 (Erp29) 등이 있다(Hebert and Molinari, 2007; Sontag et al., 2017). 그리고 소포체가 정상적인 post-translational modification step의 환경을 제공을 위하여서는 세포질에 비 하여 10 100배 정도 높은 칼슘 농도가 sarcoplasmic reticulum $\mathrm{Ca}^{2+}$-ATPase (SERCA)에 의해서 유지되어야 한다 (Periasamy and Kalyanasundaram, 2007). 세포의 정상적인 기능 수행에 역행하는 비정상적인 세포생리현상이 소포체 에 직접적으로 문제를 발생시키면 질병으로 나타난다, 이 들을 총괄하여 ER storage disease (ERSD)라고 한다(Kim and Arvan, 1998). 지금까지 보고된 대표적인 ERSD는 선천 성 갑상선 기능 저하증(congenital hypothyroidism), 요붕증 (diabetes insipidus), 골형성부전증(osteogenesis imperfect),

* Received: October 20, 2017 / Revised: November 25, 2017 / Accepted: December 8, 2017

${ }^{\S}$ Authors contributed equally to this work.

${ }^{\dagger}$ Corresponding author: O-Yu Kwon. Department of Anatomy \& Cell Biology, College of Medicine, Chungnam National University, Daejeon 35015, Korea. Tel: +82-42-580-8206, Fax: +82-42-586-4800, e-mail: oykwon@cnu.ac.kr

(C) The Korean Society for Biomedical Laboratory Sciences. All rights reserved.

(c) This is an Open Access article distributed under the terms of the Creative Commons Attribution Non-Commercial License (http://creativecommons.org/licenses/by-nc/3.0/) which permits unrestricted non-commercial use, distribution, and reproduction in any medium, provided the original work is properly cited. 


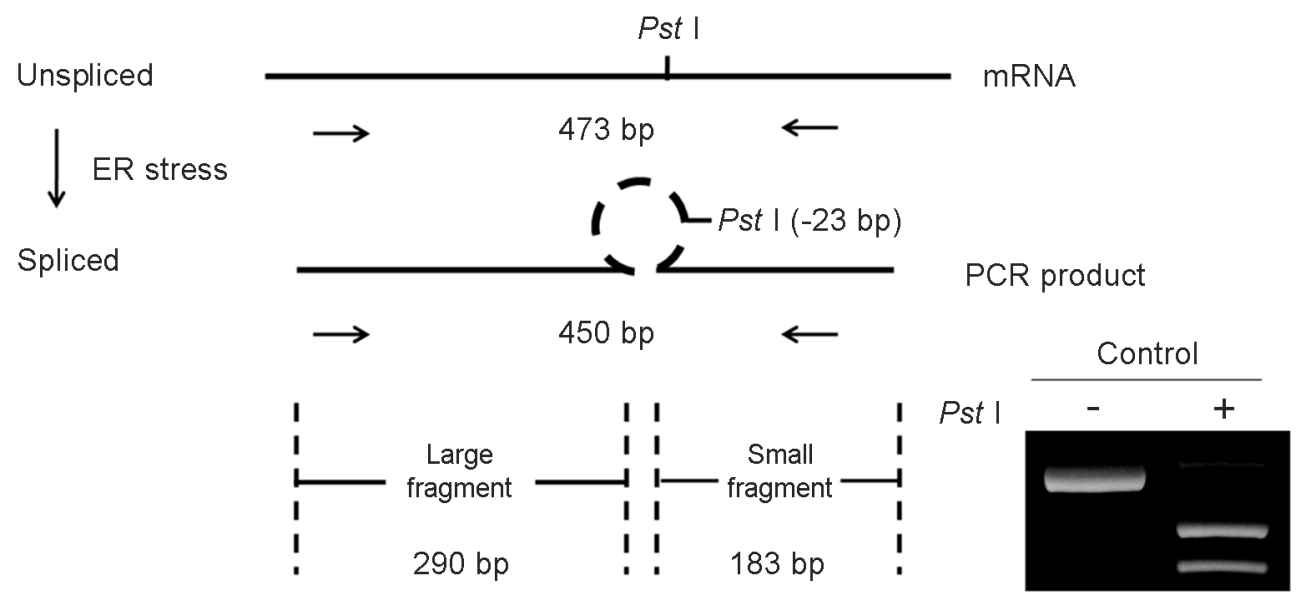

Fig. 1. Schematic representation of XBP1 mRNA splicing detection by RT-PCR. RT-PCR analysis of total RNA was performed to simultaneously detect both spliced and unspliced XBP1 mRNA, which is $473 \mathrm{bp}$ without ER stress, but when ER stress is applied, $450 \mathrm{bp}$, which is $23 \mathrm{bp}$ away, is detected. The removed $23 \mathrm{bp}$ contains the restriction enzyme Pst 1 . When PCR product was digested with restriction enzyme Pst 1 , mRNA under ER stress condition was 473 bp, but mRNA without ER stress was cleaved, resulting in 183 bp and 290 bp on the $2 \%$ agarose gel, respectively.

지질대사이상(disorders of lipid metabolism, 당뇨병(diabetes mellitus)에 관련된 40 여종이 있다. ERSD와 같이 비정상 적으로 folding된 변성 단백질(malfolded/unfolded/misfolded protein)의 축적 및 단백질 assembly가 나타나면, 세포는 소 포체 스트레스(ER stress)를 받는다. 소포체가 핵으로 소포 체 신호전달(ER signal pathway)을 통해서, 세포의 전체적 인 단백질 대사율을 억제하는 방법과 소포체 내에 축적되 는 변성 단백질의 직접적인 억제, 보호 및 수복과 같은 일 을 함으로서 세포의 homeostasis를 유지하려고 한다. ER signal pathway는 3종류의 소포체 막 단백질(IRE1: inositolrequiring enzyme 1, PERK: PKR-like ER kinase, ATF6: activating transcription factor 6)에 의해서 조절된다(Back and Kaufman, 2012; Plaquet et al., 2015; Navid and Colbert, 2017). 세포가 ER stress를 받게 되면 ER lumen의 BiP과 결합하 고 있던 monomer 상태의 IRE1이 dimmer가 되면서 X-box binding protein-1 (XBP1) mRNA의 splicing이 일어나 XBP1 단백질이 생산되어 ER chaperone을 생합성을 촉진한다. PERK 역시 monomer 상태에서 ER stress에 의해서 dimerization 되면서 핵전사인자인 eIF2 $\alpha$ (eukaryotic initiation factor $2 \alpha$ )가 인산화가 일어나 세포 전체의 단백질 생합성을 억 제한다. ATF6은 ER stress를 받으면 세포질 쪽의 단편이 떨어져 ER stress element (ERSE)에 결합하여 ER chaperone 의 생합성을 촉진한다.

인체에 적용하는 저체온법(hypothermia treatment)은 체온
을 $35^{\circ} \mathrm{C}$ 이하(일반적으로 $\left.32^{\circ} \mathrm{C}\right)$ 로 유지하여 발병의 진전 속도를 억제하는 것과 좋은 임상적인 예후를 얻기 위한 수단으로 사용되고 있다(Lee et al., 2017). 가장 효과적인 저체온법을 American Heart Association의 therapeutic hypothermia 가이드라인에서는 $32 \sim 34^{\circ} \mathrm{C}$ 에서 12 24시간으로 규정하였다(Brooks and Morrison, 2008). 실제로 refractory intracranial hypertension과 malignant cerebral edema의 경우 는 아주 유의적인 결과를 얻었다(Imataka and Arisaka, 2015). 비록 저체온법이 neurocritical care와 patient rehabilitation에 많은 장점이 알려지고 있지만 정확한 분자수준의 기전은 명확하게 규명되어 있지 않다(Kwon et al., 2008; Kuroda, 2016). 그러나 아포토시스(apoptosis), mitochondrial dysfunction, 염증(inflammation), blood-brain barrier disruption, 자유 라디칼 생성(free radical production), rescue of the RNAbinding motif protein 3 gene 등이 보고되고 있다(Yenari and Zhao, 2003; Yenari and Han, 2012; Guo et al., 2016). 본 연구에 서는 저체온법 과정이 세포에 어떤 영향을 미치는지를 알 기 위하여 ER stress의 정도를 XBP1 mRNA splicing을 이용 한 RT-PCR로 확인하였다(Kwon et al., 2005). Fig. 1의 모식 도에서 보는 것과 같이, ER stress에 의해서 IRE1 dimerization을 통해서 XBP1 mRNA splicing이 일어나면 가운데 부분의 $23 \mathrm{nt}$ 단편이 제거된다. 이 단편속에 제한효소 $P s t \mathrm{I}$ site가 존재하기 때문에 ER stress를 받아서 $23 \mathrm{nt}$ 가 분리된 상태의 RT-PCR 산물은 제한효소 PstI을 처리하여도 절단 
되지 않는다. 그러나 ER stress를 받지 않은 XBP1 mRNA 에는 PstI site를 가지고 있기 때문에, 이것의 RT-PCR 산 물에 제한효소 $P s t \mathrm{I}$ 을 처리하면 중간이 절단된다. 즉 $\mathrm{ER}$ stress를 받으면 $450 \mathrm{bp}(-23 \mathrm{nt})$ 가 나타나지만 ER stress를 받지 않으면 $473 \mathrm{bp}(+23 \mathrm{nt})$ 와 $473 \mathrm{bp}$ 단편의 중앙에 PstI 으로 절단된 2 개의 단편 $(290 \mathrm{bp}, 183 \mathrm{bp})$ 이 나타난다. 이처 럼 제한효소 Pst $\mathrm{I}$ 처리에 따라서 각각 다른 길이로 절단 되는 특성을 이용하여 hypothermia가 세포에 어느 정도의 ER stress로 작용하는지를 구별할 수 있다.

PC12 세포는 collagen-coated flask에서 85\% RPMI 1640 배지(25 mM HEPES buffer, 10\% heat inactivated horse serum, $5 \%$ heat-inactivated fetal bovine serum, $2 \mathrm{mM}$ L-glutamine, $1 \mathrm{mM}$ sodium pyruvate, $1 \mathrm{~g} / \mathrm{l} \mathrm{D}-(+)$-glucose, $25 \mu \mathrm{g} / \mathrm{ml}$ streptomycin, $25 \mathrm{U} / \mathrm{ml}$ penicillin을 포함)사용하여 $37^{\circ} \mathrm{C} / 5 \% \mathrm{CO}_{2}$ 조 건에서 배양하였다. 세포의 hypothermia 처리 온도는 $32^{\circ} \mathrm{C}$ 였다. RNA zol-B Kit (TEL-TEST, Inc. TX, USA)를 사용 total $\mathrm{RNA}$ 를 분리하였다. 충실도 $80 \%$ 의 $\mathrm{PC} 12$ 세포를 여러 조 건의 hypothermia 처리한 후 $4{ }^{\circ} \mathrm{C}$ phosphate-buffered saline (PBS)로 2회 세척 후 RNA zol-B $1 \mathrm{ml}$ 에 homogenization 하 였다. Chloroform $200 \mu \mathrm{l}$ 을 첨가하여 잘 섞어주고 12,000 $\mathrm{rpm}\left(4^{\circ} \mathrm{C}\right)$ 에서 15 분간 원심 분리하여 얻은 $500 \mu \mathrm{l}$ 의 상층 액에 $500 \mu \mathrm{l}$ 의 isopropanol를 첨가하여 $12,000 \mathrm{rpm}\left(4^{\circ} \mathrm{C}\right)$ 에 서 10 분간 원심 분리하여 침전물을 얻었다. 침전물을 $75 \%$ ethanol $\left(4^{\circ} \mathrm{C}\right) 0.1 \mathrm{ml}$ 로 세척 후 공기중에 건조하여 $\mathrm{DW}$ 에 녹인 후 NanoDrop Lite UV-spectrophotometer (Thermo Scientific, Waltham, MA, USA)로 정량하였다. 세포에서 추 출한 mRNA의 poly A에 oligo d(T) primer를 결합시켜 역전 사 효소를 이용해 $\mathrm{cDNA}$ 를 합성하였다. 주형 $\mathrm{cDNA}$ 에 대 한 DNA primer, dNTP, 내열성 DNA polymerase를 함유하 는 반응액 중에 목적으로 하는 double strand DNA를 열 변 성하였다 $\left(94^{\circ} \mathrm{C}, 30 \mathrm{sec}\right)$. 열 변성에 의해 생긴 single strand DNA에 primer를 annealing 하였다 $\left(55^{\circ} \mathrm{C}, 30 \mathrm{sec}\right)$. DNA polymerase에 의한 상보성 DNA를 합성하였다. 열 변성부터 상보성 DNA 합성까지 25 30 cycle을 반복하는데, 목적 DNA 단편에 따라 최대 효율을 얻을 수 있는 조건이 달 라서 적당하게 설정 조건을 조절할 필요가 있다. $\mathrm{PCR}$ 의 template로 사용하기 위해 M-MLV (Promega)를 이용하여 $\mathrm{cDNA}$ 를 합성하였다. 분리한 $3 \mu \mathrm{g}$ 의 RNA를 oligo $\mathrm{d}(\mathrm{T})$, nuclease-free water와 함께 $1.5 \mathrm{ml}$ tube에 넣고 $70^{\circ} \mathrm{C}$ 에서 5 분간 가열하여 denature 시킨 다음 얼음에서 차게 식힌 후, M-MLV 5X reaction buffer $6 \mu \mathrm{l}$, dNTP mixture $(2.5 \mathrm{mM})$ $4 \mu \mathrm{l}$, M-MLV RT 200 units, 재조합 RNasin ${ }^{\circledR}$ Ribonuclease
Inhibitor 25 unit를 첨가하고 nuclease-free water로 최종 반 응량을 $30 \mu \mathrm{l}$ 로 맞춘 다음 $42^{\circ} \mathrm{C}$ 에서 90 분간 반응시켰다. 반응 후에는 $95^{\circ} \mathrm{C}$ 에서 2 분간 M-MLV RT를 inactivation 시 킨 후 Nuclease-Free Water $70 \mu \mathrm{l}$ 을 더하여 최종적으로 100 $\mu \mathrm{l}$ 로 맞춘 다음 $\mathrm{PCR}$ 에 $2 \mu \mathrm{l}$ 씩 사용하였다. $\mathrm{PCR}$ 반응액 $50 \mu$ 에 F-primer (5'-AAACAGAGTAGCAGCTCAGACTGC3')와 R-primer (5'-TCCTTCTGGGTAGACCTCTGGGAG-3') 를 $94^{\circ} \mathrm{C} \sim 30$ 초, $68^{\circ} \mathrm{C} \sim 30$ 초, $72^{\circ} \mathrm{C} \sim 1$ 분으로 30 회 반복하였 다. $\mathrm{PCR}$ 최종 산물 $8 \mu \mathrm{l}$ 을 $P s t \mathrm{I}$ 제한효소로 $37^{\circ} \mathrm{C}$ 에서 2 시 간 동안 처리한 다음에 $2 \%$ agarose gel에서 전기영동하여 $\mathrm{UV}$ 상에서 밴드를 관찰하였다.

$\mathrm{PC} 12$ 세포를 $32^{\circ} \mathrm{C}$ 에서 각각 정해진 시간 동안 저온 처 리하였다(Fig. 2A). 정상적 세포 배양 온도 $\left(37^{\circ} \mathrm{C}\right)$ 에서 배양 한 대조군의 세포에 비교하여 $1,3,7$ 시간 저온 처리된 세 포가 ER stress를 덜 받는 경향을 보였다. 이는 저온에서 세포의 전체적인 대사가 떨어지는 떨어지는 것과 관계가 있는 것 같다. 그러나 저온 처리를 3 일 동안 할 경우에는 오히려 세포가 ER stress를 정상세포의 2배 정도 받았다 (Fig. 2B). 결국 세포에 미치는 저온의 영향은, 단기간에는 저 대사 상태로 ER stress가 일시적으로 약해지지만 긴 시 간에서는 ER stress로 작용하였다. 1 일 동안 저온 처리에서 는 ER stress를 거의 받지 않았으나, 1 일 저온 처리 다음에 1 시간에서 3 시간 정도 $37^{\circ} \mathrm{C}$ 처리를 하면 대조군보다 약 2배 가까이 ER stress를 받으며 5시간 처리에서는 대조군 수준으로 내려왔다(Fig. 2C). 2일간 저온 처리 후 Fig. 1과 같이 $37^{\circ} \mathrm{C}$ 처리를 $1,3,5$ 시간 처리한 결과의 형태는 Fig. $1 \mathrm{C}$ 와 유사하였다(Fig. 2D). 이 결과는 비록 1 2일의 저온 처리 후에 $1 \sim 3$ 시간 정도의 $37^{\circ} \mathrm{C}$ 처리에 의해서 ER stress 를 많이 받는 상태가 되지만 5시간 정도에서는 대조군 수 준으로 돌아오는 것을 알 수 있다. Fig. 2D에서와 같이 2시 간 저온 처리 후 $37^{\circ} \mathrm{C}$ 처리하면 $\mathrm{ER}$ stress를 받는다. 이 상 태에서 다시 $32^{\circ} \mathrm{C}$ 처리한 결과 $\mathrm{ER}$ stress가 미미하지만 상 승하는 반면 다시 $37^{\circ} \mathrm{C}$ 처리에 의해서 ER stress를 덜 받 았다(Fig. 2E). 이 결과는 $32^{\circ} \mathrm{C}$ 와 $37^{\circ} \mathrm{C}$ 처리를 반복함으로 서 ER stress를 줄일 수 있다, 만약에 저온 처리법을 치료 로 사용할 경우에 일정한 간격으로 $37^{\circ} \mathrm{C}$ 처리를 함으로서 원하지 않는 ER stress를 줄일 수 있는 가능성을 보인다. 저온 처리세포에서 $\mathrm{LiCl}$ 처리와 관계없이 GSK-3 $\beta \mathrm{pS} 9$ 가 증가되는 연구 결과가 보고되어 있다(Bretteville et al., 2012). 이는 Fig. $2 \mathrm{~B}$ 의 결과와 같이 저온 처리에 의해서 ER stress 를 받는 것을 의미한다. 그리고 $\mathrm{LiCl}$ 에 의한 $\mathrm{GSK}-3$ 저해 가 저온 처리된 세포에서 저체온 유발 tau과 인산화를 감 
(A)

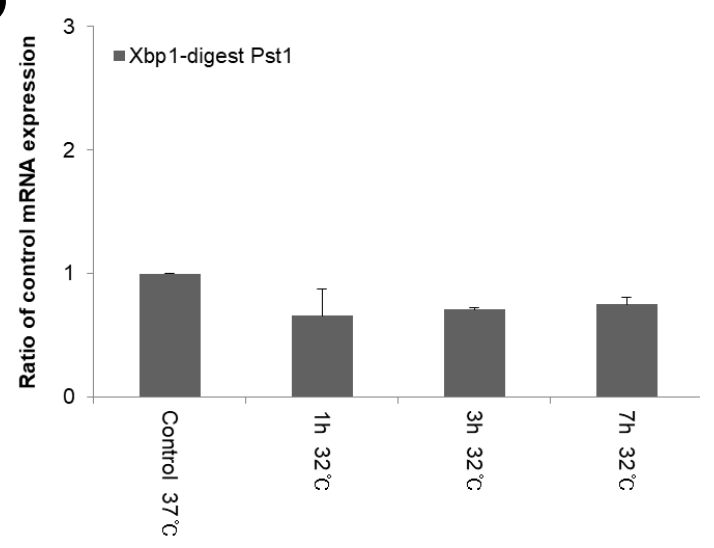

C

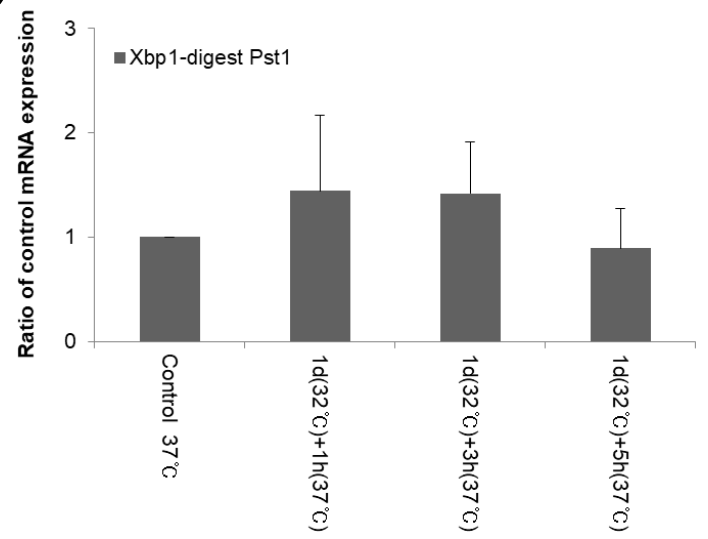

E

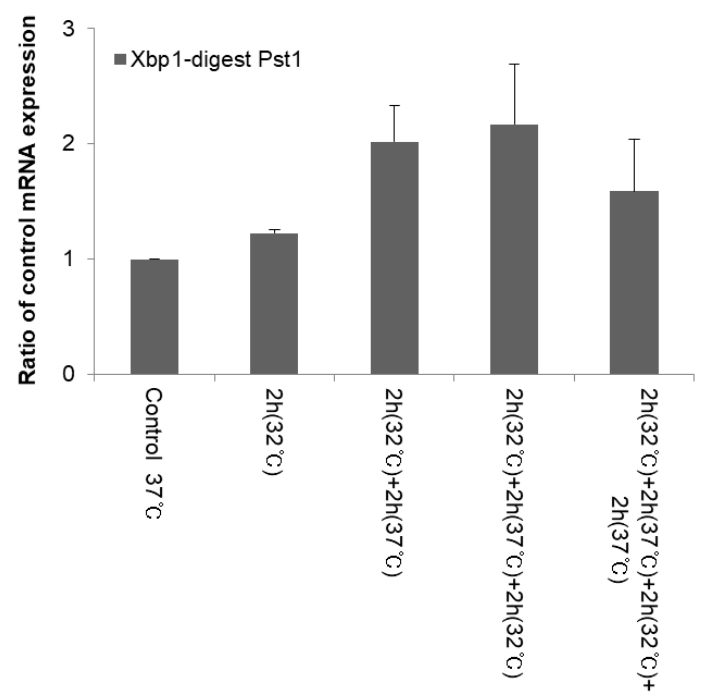

B

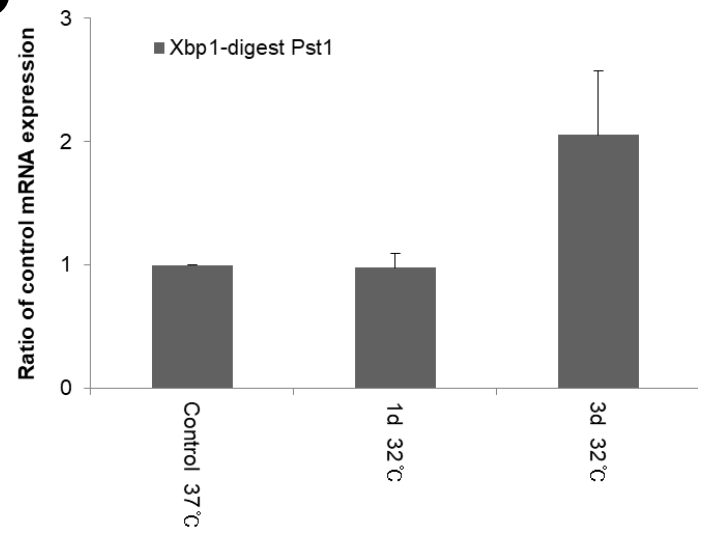

(D)

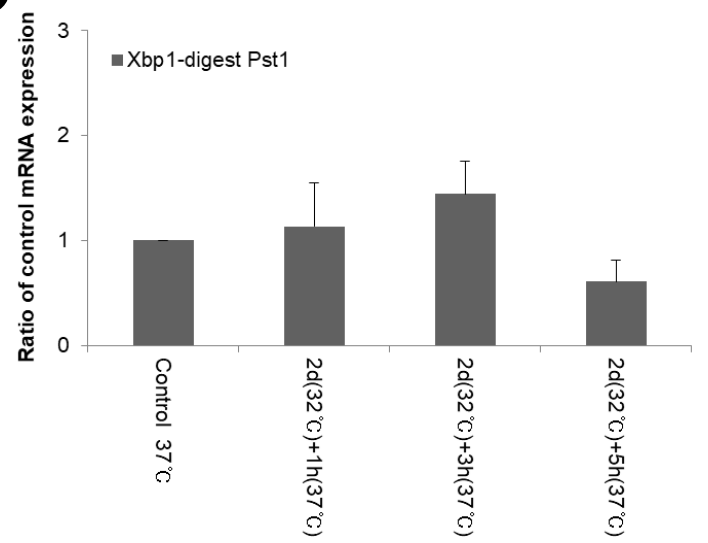

$\mathbf{F}$

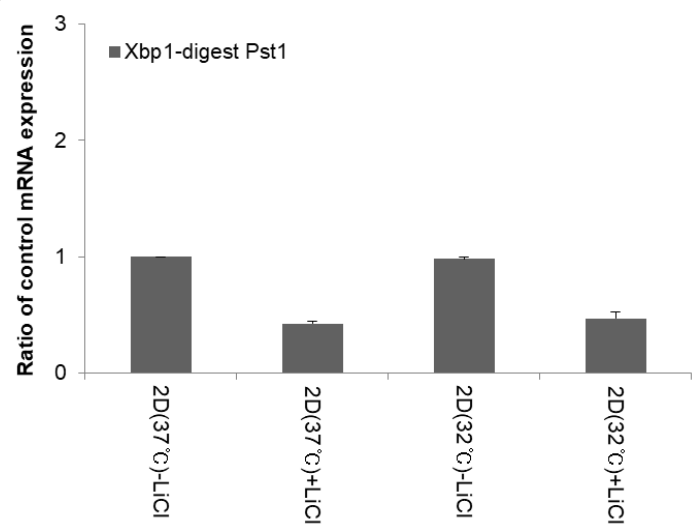

Fig. 2. The effects of hypothermia treatment for the ER stress detected by XBP1 mRNA splicing. (A) PC12 cells were exposed to hypothermia $\left(32^{\circ} \mathrm{C}\right)$ for different time durations $(1,3 \& 7 \mathrm{~h})$. (B) PC12 cells were exposed to hypothermia for different time durations $(1$ day \& 3 days). (C) \& (D) PC12 cells under control after hypothermia treatment for different time durations. (E) PC12 cells were exposed to hypothermia for repeated processing of intervals. (F) PC12 cells were exposed to hypothermia conditions with $20 \mathrm{mM}$ lithium chloride, respectively. The control treatment temperature for all experiments is $37^{\circ} \mathrm{C}$. Total RNA was isolated from indicated cells after treatment hypothermia, and the expression levels of the indicated genes were determined by RT-PCR and Pst 1 digestion, the resulting undigested Pst 1 fragments were normalized against GAPDH expression. DNA bands were quantified using the ImageJ program (NIH, Bethesda, MD, USA). The experiment was carried out three times and the results are statistically processed. 
소를 통해서 ER stress를 현저하게 감소시키는 것으로 추 정할 수 있다(Rzechorzek et al., 2015). 그러나 본 실험 결 과는 $\mathrm{LiCl}$ 처리세포에서 저온 처리와 관계없이 ER stress 가 감소되었다(Fig. $2 \mathrm{~F}$ ). 저온 처리에 의한 GSK-3 저해와 $\mathrm{tau}$ 의 발현과 인산화를 통한 ER stress를 조절기전을 분명 하게 할 필요가 있다. 그 결과는 ER stress를 최소화한 저 체온법 사용에 근본적인 문제해결에 실마리를 제공할 것 이다.

\section{ACKNOWLEDGEMENTS}

이 연구는 충남대학교 학술연구비에 의해 지원되었음.

\section{CONFLICT OF INTEREST}

The authors have no conflicts of interest to disclose.

\section{REFERENCES}

Back SH, Kaufman RJ. Endoplasmic reticulum stress and type 2 diabetes. Annual Review of Biochemistry. 2012. 81: 767-793.

Bretteville A, Marcouiller F, Julien C, El Khoury NB, Petry FR, Poitras I, Mouginot D, Lévesque G, Hébert SS, Planel E. Hypothermia-induced hyperphosphorylation: a new model to study tau kinase inhibitors. Scientific Reports. 2012. 2: 480.

Brooks SC, Morrison LJ. Implementation of therapeutic hypothermia guidelines for post-cardiac arrest syndrome at a glacial pace: seeking guidance from the knowledge translation literature. Resuscitation. 2008. 77: 286-292.

Guo C, Geng Y, Song F, Huo Y, Wu X, Lv J, Ge A, Fan W. Mild hypothermia protects rat neuronal injury after intracerebral hemorrhage via attenuating endoplasmic reticulum response induced neuron apoptosis. Neuroscience Letters. 2016. 635: $17-23$.

Hebert DN, Molinari M. In and out of the ER: protein folding, quality control, degradation, and related human diseases. Phys iological Reviews. 2007. 87: 1377-1408.

Imataka G, Arisaka O. Brain hypothermia therapy for childhood acute encephalopathy based on clinical evidence. Experimental and Therapeutic Medicine. 2015. 10: 1624-1626.

Kim PS, Arvan P. Endocrinopathies in the family of endoplasmic reticulum (ER) storage diseases: disorders of protein trafficking and the role of ER molecular chaperones. Endocrine Reviews. 1998. 19: 173-202.

Kuroda Y. Neurocritical care update. Journal of Intensive Care. 2016. 4: 36
Kwon BK, Mann C, Sohn HM, Hilibrand AS, Phillips FM, Wang JC, Fehlings MG. Hypothermia for spinal cord injury. Spine Journal. 2008. 8: 859-874.

Kwon K, Goo TW, Kwon OY. Development of rapid detection method for unfolded protein response in the mammalian cells. Journal of Experimental and Biomedical Sciences. 2005. 11: 249-252.

Lee JH, Zhang J, Yu SP. Neuroprotective mechanisms and translational potential of therapeutic hypothermia in the treatment of ischemic stroke. Neural Regeneration Research. 2017. 12: 341-350.

Navid F, Colbert RA. Causes and consequences of endoplasmic reticulum stress in rheumatic disease. Nature Reviews. Rheumatology. 2017. 13: 25-40.

Periasamy M, Kalyanasundaram A. SERCA pump isoforms: their role in calcium transport and disease. Muscle Nerve. 2007. 35: $430-442$

Plaquet O, Pourtier A, Abbadie C. The unfolded protein response and cellular senescence. A review in the theme: cellular mechanisms of endoplasmic reticulum stress signaling in health and disease. Cell Physiology. 2015. 308: 415-425.

Rzechorzek NM, Connick P, Livesey MR, Borooah S, Patani R, Burr K, Story D, Wyllie DJ, Hardingham GE, Chandran S. Hypothermic preconditioning reverses Tau ontogenesis in human cortical neurons and is mimicked by protein phosphatase 2A inhibition. EBio Medicine. 2015. 3: 141-154.

Schwarz DS, Blower MD. The endoplasmic reticulum: structure, function and response to cellular signaling. Cellular and Molecular Life Sciences. 2016. 73: 79-94.

Sontag EM, Samant RS, Frydman J. Mechanisms and functions of spatial protein quality control. Annual Review of Biochemistry. 2017. 86: 97-122.

Yenari MA, Zhao H, Giffard RG, Sobel RA, Sapolsky RM, Steinberg GK. Therapy and hypothermia for stroke treatment. Annals of the New York Academy of Sciences. 2003. 993: 54-68.

Yenari MA, Han HS. Neuroprotective mechanisms of hypothermia in brain ischaemia. Nature Reviews. Neuroscience. 2012. 13. 267-278.

https://doi.org/10.15616/BSL.2017.23.4.416

Cite this article as: $\mathrm{BK}$ Yoo, $\mathrm{K}$ Kwon, ER Lee, OY Kwon. Hypothermia Regulates Endoplasmic Reticulum (ER) Stress through the X-box Binding Protein-1 (XBP1) Gene Expression in PC12 Cells. Biomedical Science Letters. 2017. 23: 416-420. 